\author{
Maria Czajkowska \\ University of Lodz \\ Faculty of Management \\ e-mail: czajkowskamaria@uni.lodz.pl
}

\title{
Uczciwość i otwartość jako wartości współczesnego nauczyciela akademickiego
}

\section{Honesty and Openness as Values of a Contemporary Academic Teacher}

The changes that contemporary organisations go through result in a shift in management conduct, organisation and management of human resources. Such trends are observable in public higher education institutions in Poland. Organisations striving to actively compete in a dynamic environment, and answer its needs, introduce amendments in various areas of their operations. Endeavours to improve the quality of teaching and ensure more efficient and effective management of higher education institutions are becoming ubiquitous. Changes are not only "cosmetic" in nature, but regularly interfere with organizational culture - and, as such, are challenging and implemented over a long time frame. Organisational culture, with values at its core, is a resultant of many factors, including values brought in by an organisation's employees. For higher education institutions, this aspect is an important starting point for further reflections. The ethos of academics, through historical determinants, is based on honesty and openness - some key values that form the basis for decision making in diverse areas of operations. This article focuses on honesty and openness as desirable social values and components of a wider social capital - trust, with the benefits of professing trust taken into account as well. At the same time, an attempt has been made to show the role of those values in the context of the work of public higher education institution employees. Theoretical considerations are backed by illustrative quantitative empirical research. Research has been conducted among employees in the positions of researchers, educators and researcher-educators in all higher education institutions operating in Lodz, Poland.

Keywords: honesty, openness, public higher education institution, academic teacher

JEL Classification: I23 


\section{(...) Dla tych ostatnich mianowicie, przyjemne sa te rzeczy, które odpowiadaja ich właściwościom charakteru. A to wtaśnie sa rzeczy dobre i moralnie piękne ${ }^{1}$.}

\section{Wprowadzenie}

Współczesne wyższe uczelnie publiczne w Polsce podlegają ciągłym transformacjom, które są pochodną zmian zachodzących w systemie prawnym, zmian demograficznych i społecznych, a także zmian technologicznych. Turbulentne otoczenie, w którym funkcjonują uczelnie, wymusza zmiany w sposobie sprawowania na nich władzy, w gospodarowaniu ich finansami, procedurach stosowanych przy rekrutacji studentów czy metodach „uprawiania” dydaktyki. Zmiany, jakim podlegają uczelnie publiczne w Polsce stanowią podstawę do rozważań nad kierunkiem, $\mathrm{w}$ jakim podążają i mają podążać uczelnie publiczne chcące zachować pozycję konkurencyjną na rynku. Pojawia się wiele problemów, z którymi ten szczególny rodzaj organizacji musi sobie radzić. Do tych problemów zaliczyć można m.in. komercjalizację nauki akademickiej, rynkowe przekształcenia uniwersytetów, erozję etosu klasycznej nauki, eliminację humanistyki ze sfery badań czy upowszechnienie się zjawiska plagiatu. Ze względu na dużą liczbę zmian występujących na różnych polach trudno jest - mimo najlepszych chęci i prób podejmowanych przez kierownictwo uczelni na różnych szczeblach - przygotować do nich wszystkich pracowników. Brak przejrzystości i otwartej komunikacji rodzi często napięcia i frustracje wśród pracowników ${ }^{2}$, co staje się powodem znacznego wzrostu liczby publikacji krytycznych wobec poszczególnych zmian, co w skrajnym przypadku może stać się powodem zwiększonej fluktuacji kadry akademickiej. Każda z opisanych zmian dotykających publicznych uczelni wyższych znajduje również swoje odzwierciedlenie w zmianie hierarchii wartości i zachowań nauczycieli akademickich, gdyż najwięcej zmian dotyczy właśnie tej grupy pracowników. Te problemy z kolei wymagają zmiany podejścia do zarządzania publicznymi uczelniami wyższymi, w tym do sposobu sprawowania władzy, która powinna spełniać wymogi transparentności, elastyczności, wiarygodności, uczciwości i otwartości. Obszarami odpowiedzialności, które dotyczą nauczycieli akademickich, są w różnych proporcjach i z różnie rozłożonymi akcentami, płaszczyzny: naukowa, dydaktyczna i organizacyjna. W każdym z nich wartości uczciwości i otwartości będą miały inne przełożenie, ale w każdym będą one odgrywały znaczącą rolę według postawionej w artykule tezy, która brzmi: w system wartości nauczyciela akademickiego wpisane są uczciwość i otwartość jako jedne z jego kluczowych wartości.

\footnotetext{
${ }^{1}$ Arystoteles, Dzieła wszystkie, Etyka Eudemejska, Księga VII, Wydawnictwo Naukowe PWN, Warszawa 1996, tom 6, s. 222.

${ }^{2}$ Gdy nie ma zaufania, szerza się plotki. Gdy nie ma zaufania, brakuje otwartej komunikacji. Gdy nie ma zaufania, pojawiaja się wątpliwości i rozczarowanie. J. Gitomer, Turkusowa ksiażeczka zaufania. Jak je zdobyć, wzmacniać i utrzymać, by stać się zaufanym doradca w biznesie $i$ w życiu, Wydawnictwo Studio EMKA, Warszawa 2011, s. 143.
} 
Ze względu na objętość opracowania postanowiono spojrzeć na wartość uczciwości i otwartości z punktu widzenia spajającego wszystkie wymienione pola i jednocześnie nie akcentując żadnego z nich.

Mimo że uczciwość i otwartość w pisaniu prac naukowych czy prowadzeniu badań (obszar naukowy), uczciwość i otwartość w stosunku do studentów i w prowadzeniu zajęć (obszar dydaktyczny), czy w końcu uczciwość i otwartość w wypełnianiu powierzonych nauczycielowi funkcji np. w organach władzy czy komisjach (obszar organizacyjny) są ważne i choć mogłyby być analizowane odrębnie, to w niniejszym artykule, $\mathrm{z}$ uwagi na jego ograniczoną objętość, potraktowane zostaną łącznie. Trzeba przyznać, że takie podejście stanowi pewne uproszczenie rzeczywistości, lecz z drugiej strony pozwala spojrzeć bardziej kompleksowo na omawiane zagadnienie. Uczciwość i otwartość zostaną więc potraktowane w niniejszym opracowaniu jako jeden z wymiarów szerszego zagadnienia, jakim jest zaufanie, i zostaną zbadane pod kątem relacji pracownik-kierownik w organizacji.

\section{Rola wartości w pracy nauczyciela akademickiego}

W tym szczególnym rodzaju organizacji, jakimi są wyższe uczelnie publiczne, kluczową rolę pełnią nauczyciele akademiccy. Zgodnie z ustawą Prawo o szkolnictwie wyższym mianem nauczycieli akademickich, zajmujących się procesem naukowodydaktycznym, określa się pracowników naukowo-dydaktycznych, pracowników dydaktycznych, pracowników naukowych ${ }^{3}$. Artykuł 109 ustawy mówi o tym, że nauczycielem akademickim może zostać osoba, która ${ }^{4}$ :

(1) posiada kwalifikacje określone w ustawie,

(2) ma pełną zdolność do czynności prawnych,

(3) nie została ukarana prawomocnym wyrokiem sądowym za przestępstwo umyślne,

(4) nie została ukarana karą dyscyplinarną wymienioną w art. 140, ust. 1, pkt 4,

(5) korzysta z pełni praw publicznych.

Ustawa nie reguluje jednak innych kwestii i wymogów dotyczących osoby nauczyciela akademickiego związanych np. z kompetencjami społecznymi. Niemniej należy pamiętać, że:

[n]auczyciel akademicki, noszac swoje chlubne miano w nawiazaniu do założonej przez Platona (...) pierwszej szkoły - Akademii Platońskiej (...), jest kontynuatorem pierwowzorów: pedagoga i systemu edukacyjnego, stworzonego przez wielkiego myśliciela i nauczyciela ${ }^{5}$.

\footnotetext{
${ }^{3}$ Art. 107 i 108 Ustawy z dnia 27 lipca 2005 r. Prawo o szkolnictwie wyższym (Dz. U. z 2012 r., poz. 572 z późn. zm.).

${ }^{4}$ Ibidem.

${ }^{5}$ A. Jeremus, Nowoczesny wizerunek nauczyciela akademickiego [w:] Nauczyciel akademicki jako ogniwo jakości kształcenia, red. K. Jankowski, B. Sitarska, C. Tkaczuk, Akademia Podlaska, Siedlce 2003, s. 61.
} 
Posiadanie kwalifikacji zawodowych jest niezbędne do wykonywania zawodu nauczyciela, aczkolwiek bez odpowiednich umiejętności interpersonalnych czy kompetencji społecznych jego rola będzie znacznie ograniczona ${ }^{6}$.

Poszczególne uczelnie wyższe tworzą kodeksy etyczne ${ }^{7}$, jednak należy zastanowić się czy istnieją pewne nadrzędne wartości, które są obowiązujące i mogą stanowić wzór dobrych praktyk etycznych, a które jednocześnie są uniwersalne (tzn. niezależne od rodzaju uczelni, stażu pracy czy miejsca w hierarchii organizacyjnej). Współczesne trendy w zarządzaniu wskazują na potrzebę takiego kształtowania kultury organizacyjnej, która będzie oparta na wartościach. Ich rola we współczesnych organizacjach nabiera kluczowego znaczenia. Stanowią one trzon ${ }^{8}$, w oparciu o który można kształtować inne elementy organizacji - motywuja ludzi także do poprawy ich indywidualnych działań na stanowisku pracy ${ }^{9}$. Trudno więc nie zgodzić się z S. Lachowskim, który twierdzi, że: [r]zecz w tym, aby wartości, pozostawaty względnie stałym elementem, który wyznacza punkt odniesienia $w$ procesie ciagłych zmian i czasach niepewnośc ${ }^{10}$. Wartościami są idee wyznawane przez jednostki lub grupy, określające co jest pożądane, właściwe, dobre, a co złe ${ }^{11}$. A. Stachowicz-Stanusch w swojej książce Potęga wartości. Jak zbudować nieśmiertelna firme, pierwszy rozdział publikacji oparła o stwierdzenie: potęga wartości, czyli dlaczego nie można bez nich żyć i należy traktować je poważnie, a rozważania skupiła wokół głównych wartości traktowanych jako ${ }^{12}$ :

(1) nośnik nieśmiertelności organizacji,

(2) dziedzictwo kulturowe przedsiębiorstwa,

(3) element integrujący pracownika z przedsiębiorstwem,

(4) katalizator atmosfery pobudzenia organizacyjnego,

(5) element motywujący jednostkę do działania,

(6) generatory zyskowności,

(7) przywabiacz talentów,

(8) czynnik wspomagający zarządzanie zmianą,

(9) drogowskaz w czasie kryzysu.

Ponieważ wartości, w odróżnieniu od celów ilościowych, nigdy w pełni i do końca nie mogą zostać zrealizowane ${ }^{13}$ to A. Kozak proponuje następujący sposób ich kształtowania w organizacji:

\footnotetext{
${ }^{6}$ I. Malorny, Wizerunek współczesnego nauczyciela - implikacje praktyczne jakości kształcenia w zawodzie [w:] W obliczu nowych wyzwań. Dylematy młodej kadry akademickiej red. M. Kulesza, M. Kafar, Wydawnictwo Uniwersytetu Łódzkiego, Łódź 2010, s. 121.

${ }^{7}$ Cf. Kodeks Etyki Nauczyciela Akademickiego Uniwersytetu Gdańskiego, http://arch.ug.edu.pl/pl/dzo rg/prawo/us/2007/zal40u07a.htm (data dostępu: 15.04.2016).

${ }^{8}$ G. Hofstede, Kultury i organizacje, Polskie Wydawnictwo Ekonomiczne, Warszawa 2000, s. 43.

${ }^{9}$ A. Stachowicz-Stanusch, Potęga wartości. Jak zbudować nieśmiertelna firmę, Helion Gliwice 2007, s. 23.

${ }^{10}$ S. Lachowski, Droga ważniejsza niż cel, Wydawnictwo Studio EMKA, Warszawa 2012, s. 337.

11 A. Giddens, Socjologia, Wydawnictwo Naukowe PWN, Warszawa 2004, s. 737.

${ }^{12}$ A. Stachowicz-Stanusch, op. cit., s. 11-33.

${ }^{13}$ Ibidem, s. 21.
} 
Prace z wartościami należy rozpoczać od jasnej definicji danej wartości, a nastęnie przełożyć ja na zachowanie - same deklaracje odnośnie ważności określonych działań nie wystarczą. Wartości, by miaty moc wiązania pracowników z organizacja, musza być wyrażane w przejrzystych i czytelnych zachowaniach ${ }^{14}$.

Należy więc zadać sobie pytanie, które wartości wydają się niezbędne z punktu widzenia współczesnych realiów pracy nauczyciela akademickiego.

\section{Uczciwość i otwartość jako wartości kluczowe}

Według Stownika Języka Polskiego „uczciwy” oznacza: rzetelny w postępowaniu, szanujący cudza wtasność, niezdolny do oszustwa; też: świadczacy o takich cechach; zgodny z przyjętymi zasadami lub prawem; zgodny z rzeczywistościa lub prawda; (pot.) taki jak należy ${ }^{15}$. Warto dodać, że uczciwość jest postrzegana przez A. Stachowicz-Stanusch jako jedna za tzw. wartości rozwoju ${ }^{16}$. Uczciwość to wywiązywanie się z obowiązów moralnych, z danego słowa, to przestrzeganie przyjętych regut moralnych ${ }^{17}$. Uczciwość jest także elementem lojalności pracowników współczesnych organizacji, w których jest interpretowana zgodnie z jej podstawowymi definicjami i wyraża się w takich zachowaniach, jak np.: postępowanie zgodnie $\mathrm{z}$ deklaracjami czy szczerość, otwarte wyrażanie swoich opinii i przekonań ${ }^{18}$.

„Otwarty” zaś to: taki, który jest gotów na przyjęcie nowych idei lub propozycji; też: o poglądach i postawie takiej osoby; taki, który nie ukrywa swoich myśli i uczuć; też: o zachowaniu i wygladzie takiej osoby ${ }^{19}$; szczery, nieobludny, prostolinijny ${ }^{20}$, jawny $i$ wyraźny, (...) taki, który jest gotów na przyjęcie nowych idei lub propozycji; też: o poglądach i postawie takiej osoby, (...) taki, który nie ukrywa swoich myśli i uczuć21.

W kontekście przedstawionych definicji wydaje się być zasadnym stwierdzenie, że w dzisiejszym turbulentnym otoczeniu w jakim przyszło funkcjonować i konkurować współczesnym uczelniom publicznym, takie wartości jak otwartość i uczciwość nabierają istotnego znaczenia. Ponieważ zaś o kierunku zmian wprowadzanych na uczelni w dużej mierze decydują jej władze, które składają się głównie z nauczycieli akademickich, warto zastanowić się nad tym, jaki poziom uczciwości i otwartości w istniejących na uczelni stosunkach władzy i w kontekście budowania kapitału społecznego ta grupa reprezentuje. Wartości uczciwości i otwartości stanowią fundament do budowania kultury sprzyjającej efektywnemu wprowadzaniu zmian. W czasach,

\footnotetext{
${ }^{14}$ A. Kozak, Zatrzymać pracownika poprzez ksztaltowanie kultury organizacyjnej, www.irb.pl/wiedza-dlabiznesu/zatrzymac-pracownika-poprzez-ksztaltowanie-kultury-organizacyjnej/ (data dostępu: 16.04.2014). ${ }^{15}$ Słownik Języka Polskiego, PWN, http://sjp.pwn.pl (data dostępu: 17.04.2016).

${ }^{16}$ A. Stachowicz-Stanusch, op. cit., s. 136.

${ }^{17}$ K. Stachewicz, Aksjologia prawdy i uczciwości. Krótkie wprowadzenie w problematykę [w:] Prawda i uczciwość w życiu publicznym, red. R. Wiśniewski, Towarzystwo Naukowe w Toruniu, Toruń 2014, s. 18. ${ }^{18}$ I. Świątek-Barylska, Lojalność pracowników wspótczesnych organizacji. Istota i elementy składowe, Wydawnictwo Uniwersytetu Łódzkiego, Łódź 2013, s. 233

19 Stownik Języka Polskiego, op. cit. (data dostępu: 17.04.2016).

${ }^{20}$ Ilustrowany Stownik Języka Polskiego, red. E. Sobol, Wydawnictwo Naukowe PWN, Warszawa 1999, s. 576.

${ }^{21}$ Stownik 100 tysięcy potrzebnych stów, red. J. Bralczyk, Wydawnictwo Naukowe PWN, Warszawa 2005, s. 525.
} 
w których zmiana jest zjawiskiem permanentnym, nabiera to szczególnego znaczenia. Wyznawanie takich wartości jak uczciwość i otwartość przez osoby piastujące na uczelni stanowiska kierownicze jest swoistym gwarantem, że zmiany nie będą odbywały się ze szkodą dla pracowników (uczciwość) i jednocześnie zgodne z obowiązującymi trendami (otwartość), a po stronie pracowników - że nie tylko będą oni gotowi zaakceptować niezbędne zmiany (otwartość), ale że będą je inicjować oddolnie, a także, gdy zajdzie taka potrzeba, będą potrafili odpowiedzialnie zaprotestować, nie bojąc się skutków czy represji ani ze strony kierownictwa ani ze strony współpracowników. Uczciwość jest więc swoistym gwarantem, że obie strony będą grały „fair”, zaś otwartość stanowi punkt wyjścia do dialogu między pracownikami a kierownictwem, między współpracownikami, a także między organizacją a jej otoczeniem. Zarówno uczciwość, jak i otwartość, jeśli są nie tylko deklarowane, ale faktycznie wyznawane, mogą pozwolić na wyeliminowanie niektórych dodatkowych kosztów społecznych i finansowych. Nie dziwią więc pojawiające się w środowisku głosy, że do zestawu cech czy też konkretnych zachowań, którymi powinien się charakteryzować współczesny nauczyciel akademicki zalicza się m.in.: wiedzę i umiejętności jej przekazywania, uczciwość i szczerość, poszanowanie poglądów innych osób, nienarzucanie studentom swojego zdania lub punktu widzenia, szczególnie w kwestiach światopoglądowych czy politycznych, tolerancję, postępowanie zgodnie ze swoimi przekonaniami, branie odpowiedzialności za swoje czyny, poczucie humoru, sprawiedliwość i szerokie zainteresowania pracowników nauki wychodzące poza granice ich specjalności naukowej ${ }^{22}$. Należy zauważyć również, że wartości takie, jak uczciwość i zaufanie - stanowia wspólny element wszystkich religii świata, uniwersalne cnoty moralne świadomych spoteczeństw, kanon moralności ${ }^{23}$, więc potwierdzają istnienie uniwersalnych standardów moralnych i etycznych, które umożliwiają przywrócenie prawości w życiu społecznym i gospodarczym. Probierzem kapitału społecznego jest zasada uogólnionej wzajemności ${ }^{24}$, a uogólniona wzajemność i uczciwość stanowia swoistego rodzaju , smar" istotnie ułatwiajacy funkcjonowanie machiny społecznej ${ }^{25}$, gdyż w każdej organizacji uczciwość odgrywa kluczową rolę, a osoby, którym lider przewodzi, muszą mu ufać i wierzyć nie tylko w jego uczciwość, ale także w to, że interesuje się on również nimi i ich aspiracjami. Lider musi być także sprawiedliwy w każdej sferze funkcjonowania, tak publicznej, jak i prywatnej ${ }^{26}$. W relacjach z uczestnikami organizacji, jak i z jej otoczeniem przywódca odgrywa bowiem rolę gwaranta zaufania ${ }^{27}$. U podstaw trwałej i twórczej kultury organizacyjnej powinien więc stać powszechny zbiór zasad etycznych, postaw i wartości, a ich promowanie

\footnotetext{
22 M. Śnieżyński, O autorytecie nauczyciela akademickiego, www.wsp.krakow.pl/konspekt/konspekt3/sniezynski.html (data dostępu: 20.02.2013).

${ }^{23}$ L.V. Ryan, Wyzwania moralne $w$ czasach transformacji gospodarczej, „Ruch Prawniczy, Ekonomiczny i Socjologiczny" 1996, vol. 58, nr 1, s. 50.

${ }^{24}$ R.D. Putnam, Samotna gra $w$ kręgle. Upadek i odrodzenie wspólnot lokalnych $w$ Stanach Zjednoczonych, Wydawnictwa Akademickie i Profesjonalne, Warszawa 2008, s. 226.

${ }^{25}$ Ibidem, s. 238.

${ }^{26}$ R.E. Palmer, Przywództwo doskonate, Wolters Kluwer business, Warszawa 2010, s. 204-205.

${ }^{27}$ A.K. Koźmiński, D. Jemielniak, Zarządzanie od podstaw, Wydawnictwa Akademickie i Profesjonalne, Warszawa 2008, s. 23.
} 
jest zadaniem kierownictwa organizacji, gdyż przykład jaki dają osoby na najwyższych stanowiskach, pomaga kształtować etykę w całej organizacji ${ }^{28}$. Do wartości pożądanych w kulturze organizacyjnej pracownicy zaliczają: lojalność, uczciwość, skuteczność, otwartość, troskę, równość ${ }^{29}$. W związku z powyższym istnieją wielowymiarowe modele zaufania, których jednym z wymiarów jest właśnie uczciwość i otwartość.

Do badania wymiaru uczciwości i otwartości w relacjach władzy w uczelniach publicznych wykorzystano wystandaryzowany kwestionariusz mierzący Wskaźnik Organizacyjnego Zaufania (OTI). Mierzy on zaufanie organizacyjne w pięciu wymiarach, do których należą: kompetencja, otwartość/uczciwość, troska o pracowników, wiarygodność, identyfikowanie się z firmą.

Do badania zaufania został wykorzystany przetłumaczony na język polski i odpowiednio dostosowany językowo gotowy kwestionariusz badawczy ${ }^{30}$. Kwestionariusz zawiera dwadzieścia dziewięć twierdzeń i została w nim zastosowana skala Likerta w celu zestandaryzowania kategorii odpowiedzi. Rzetelność narzędzia (tak oryginalnego narzędzia, jak i jego odpowiednika w języku polskim) została potwierdzona badaniem współczynnika Alfa Cronbacha, który wyniósł 0,92 ${ }^{31}$. Ankieta skierowana była do pracowników naukowych, naukowo-dydaktycznych i dydaktycznych pracujących w wyższych uczelniach publicznych na terenie Łodzi. Nie badano pracowników pracujących w filiach tychże uczelni.

Ponieważ uzyskano zgody wszystkich Rektorów na przeprowadzenie badań (pod warunkiem podania wyników w opracowaniach zbiorowych), badaniu poddano pracowników wszystkich sześciu wyższych uczelni publicznych z terenu Łodzi, w tym trzech o profilu artystycznym (Akademia Muzyczna im. Grażyny i Kiejstuta Bacewiczów w Łodzi, Akademia Sztuk Pięknych im. Władysława Strzemińskiego w Łodzi, Państwowa Wyższa Szkoła Filmowa, Telewizyjna i Teatralna im. Leona Schillera $\mathrm{w}$ Łodzi) oraz trzech reprezentujących profile: humanistyczny (Uniwersytet Łódzki), techniczny (Politechnika Łódzka) i medyczny (Uniwersytet Medyczny w Łodzi). Przeprowadzone badania miały charakter ilościowy i ilustracyjny. Dane zbierane były metodą ankietową pośrednią bez udziału ankietera (ankieta internetowa).

\footnotetext{
${ }^{28}$ M. Rybak, Etyka menedżera - społeczna odpowiedzialność przedsiębiorstwa, Wydawnictwo Naukowe PWN, Warszawa 2004, s. 128-129.

${ }^{29}$ H. von Weltzien Hoivik, Accessing, Managing and Sustaining Moral Values in Organizations: a Case Study [w:] Moral Leadership in Action. Building and Sustaining Moral Competence in European Organizations, red. H. von Weltzien Hoivik, Edward Elgar Publishing, Cheltenham, 2003, s. 117.

${ }^{30}$ P. Shockley-Zalabak, K. Ellis, R. Cesaria, Building the High-Trust Organization, John Wiley \& Sons, IABC Research Foundation, 2010.

Kwestionariusz badawczy mierzący zaufanie organizacyjne we wszystkich jego wymiarach został przetłumaczony na język polski i dostosowany do grupy respondentów, a następnie skonsultowany z ekspertem.

${ }^{31}$ Współczynnik równy 1 oznacza $100 \%$ rzetelność.
} 


\section{Wyniki badań empirycznych}

W badaniu udział wzięło 744 respondentów, co stanowi 12,99\% populacji generalnej. Wśród badanych kobiety stanowiły 52,6\% wszystkich respondentów. 10,3\% respondentów pełniło w uczelniach funkcje kierownicze. Najmniej liczną grupę stanowili profesorowie $(10,6 \%)$, a następnie doktorzy habilitowani (12,6\%). Liczniejszą grupę stanowiły osoby z dyplomem magistra (22,9\%), a najliczniejszą - ze stopniem doktora $(53,9 \%)$. Wskaźnik podobieństwa struktur wyniósł 95,2\%, co świadczy o bardzo dużym podobieństwie próby i populacji pod względem tytułów naukowych.

Zanim przystąpiono do analizy poszczególnych składników wymiaru uczciwość/otwartość, dokonano zestawienia wyników badań własnych dla tego wymiaru z wynikami badań wtórnych, przeprowadzanych w środowisku wielokulturowym dla różnorakich firm, w tym organizacji o charakterze edukacyjnym. Porównanie dotyczyło wyników uzyskanych z kwestionariusza przetłumaczonego na język polski z wynikami, uzyskanymi przez twórców modelu OTI ${ }^{32}$. Można było tego dokonać, ponieważ narzędzie było wystandaryzowane, uwzględniało aspekt kulturowy oraz przeprowadzone badania uwzględniały również uczelnie wyższe.

Zestawienie wyników porównania przedstawia wykres 1. Jak można zauważyć, średnia dla wymiaru otwartość/uczciwość dla uczelni (skala 1-5; średnia 3) jest wyższa niż dla firm i różnica ta okazała się być najwyższa z wszystkich analizowanych wymiarów zaufania.

Wykres 1. Porównanie wyników badań własnych wymiaru otwartość/uczciwość z wynikami badań wtórnych

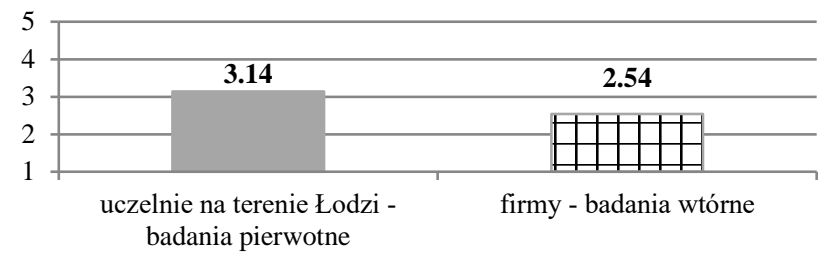

Źródło: opracowanie na podstawie badań własnych oraz P. Shockley-Zalabak, K. Ellis, R. Cesaria, Building the High-Trust Organization, John Wiley \& Sons, IABC Research Foundation, 2010, s. 17-23.

Dokonano analizy korelacji rho-Spearmana. Korelacje wymiaru otwartość/uczciwość z poszczególnymi składowymi tej zmiennej w różnych grupach respondentów (tytuł/stopień naukowy, rodzaj uczelni, pełniona funkcja kierownicza) przedstawia tabela 1 . W analizie uwzględniono wyłącznie te zależności, które okazały się istotne

\footnotetext{
${ }^{32}$ Dokładny opis grupy respondentów biorących udział w badaniu oraz szczegółowe wyniki badań znajdują się w publikacji: P. Shockley-Zalabak, K. Ellis, R. Cesaria, Building the High-Trust Organization, John Wiley \& Sons, IABC Research Foundation, 2010.
} 
statystyczni $^{33}(\mathrm{p}<0,05)$. Najsilniejszy związek $(0,914)$ wystąpił pomiędzy wymiarem otwartości/uczciwości a pytaniem dotyczącym otrzymywania rzetelnych informacji na temat sposobu, w jaki rozwiązywane są problemy pracowników w typie uczelni artystycznych. Co interesujące, również dla uczelni nieartystycznych związek ten jest dość silny $(0,824)$. Jednocześnie pytanie to pozostaje w ścisłym związku z wymiarem otwartości/uczciwości dla wszystkich grup respondentów, bez względu na rodzaj uczelni, tytuł czy pełnioną funkcję kierowniczą, a także płeć. Wszystkie opisane zależności są istotne statystycznie, a wartości współczynnika korelacji wahają się od 0,809 do 0,873 (tabele 1 i 2).

Podobna sytuacja dotyczy pytania na temat tego, jak pracownik radzi sobie w pracy, choć w tym przypadku analiza nie stwierdziła tak silnego związku. Mimo tego we wszystkich grupach respondentów występuje podobnie silna korelacja z wymiarem otwartości/uczciwości (od 0,784 do 0,880). Interesujący wydaje się również fakt, że analiza zebranych danych pozwoliła na stwierdzenie, że istnieje statystycznie istotny związek pomiędzy wymiarem otwartości/uczciwości ze względu na typ uczelni w przypadku uczelni artystycznych, a takimi składowymi zmiennej jak: dochowanie tajemnicy przez przełożonego, otrzymywanie rzetelnych informacji dotyczących zasad oceny pracowników czy otrzymywanie rzetelnych informacji o decyzjach podjętych na uczelni, które mają wpływ na pracę pracowników. Związki te okazały się być dość silne, a najsilniejszy z nich dotyczył zasad oceny pracy $(0,858)$. W przypadku uczelni nieartystycznych nie stwierdzono korelacji istotnej statystycznie (Tabela 1). Jednocześnie warto podkreślić, że w przypadku pełnienia funkcji kierowniczej/niekierowniczej, nie stwierdzono zależności istotnych statystycznie. Stwierdzono zaś istotny statystycznie związek pomiędzy wymiarem uczciwości/otwartości, a pytaniem dotyczącym możliwości niezgadzania się z bezpośrednim przełożonym dla uczelni artystycznych, ale współczynnik korelacji jest w tym przypadku dość słaby $(0,395)$.

Dokonując analizy pod względem płci respondentów korelację dość silną $\mathrm{i}$ istotną statystycznie pomiędzy wymiarem otwartości/uczciwości a dwiema składowymi zmiennej stwierdzono w przypadku grupy kobiet. Pierwsze pytanie dotyczyło możliwości zwrócenia się do swojego przełożonego, gdy pojawią się problemy $(0,727)$ a drugie otrzymywania rzetelnych informacji o decyzjach podjętych na uczelni, które mają wpływ na wykonywaną pracę $(0,713)$. W przypadku grupy mężczyzn stwierdzono brak korelacji istotnej statystycznie. W przypadku obu opisywanych grup ze względu na płeć respondentów stwierdzono korelacje istotne statystycznie między wymiarem otwartości/uczciwości a pytaniem dotyczącym oceny pracy pracownika. Opisane zależności przedstawia Tabela 2. Biorąc pod uwagę stopień/tytuł naukowy respondentów warty podkreślenia wydaje się fakt, że wysoki stopień korelacji istotnej statystycznie stwierdzono pomiędzy wymiarem otwartości/uczciwości a pytaniem o możliwość zwrócenia się do bezpośredniego przełożonego z pytaniem, gdy pojawią się problemy w pracy w grupie magistrów i doktorów.

\footnotetext{
${ }^{33} \mathrm{~W}$ badaniach społecznych umownym progiem poziomu istotności jest 0,05 . Gdy istotność dla danego wyniku jest mniejsza niż 0,05 , to oznacza, że istnieją istotne statystycznie różnice w ocenach ze względu na płeć, rodzaj uczelni, pełnione funkcje kierownicze czy stopień/tytuł.
} 
W przypadku doktorów habilitowanych i profesorów nie stwierdzono takiej zależności. Jednocześnie dość silny współczynnik korelacji $(0,728)$ stwierdzono w przypadku zależności między wymiarem otwartości/uczciwości a pytaniem o uczestnictwo w podejmowaniu decyzji dotyczących pracy pracowników w grupie profesorów, co wydaje się logicznym wnioskiem, gdyż zwykle to właśnie ta grupa stanowi grupę decyzyjną w uczelniach wyższych (por. Tabela 2).

Znamienne zaś jest to, że jedynie w przypadku grupy magistrów, istnieje korelacja istotna statystycznie między wymiarem otwartości/uczciwości a pytaniem dotyczącym otrzymywania rzetelnych informacji o decyzjach podjętych w uczelni, które mają wpływ na ich pracę $(0,750)$ oraz pytaniem dotyczącym umiejętności dochowania tajemnicy przez bezpośredniego przełożonego $(0,730)$. Na podstawie przeprowadzonej analizy stwierdzono istotną statystycznie korelację pomiędzy wymiarem otwartości/uczciwości a pytaniem dotyczącym rzetelnych informacji na temat zasad oceny pracy pracowników w grupach magistrów, doktorów i profesorów. Co ciekawe takiej zależności istotnej statystycznie nie stwierdzono tylko w jednej grupie badanych - w grupie doktorów habilitowanych. Opisane zależności przedstawione zostały w tabeli 2.

\section{Podsumowanie}

Na podstawie przeprowadzonych badań można stwierdzić, że otwartość i uczciwość są wartościami wyznawanymi przez ponad połowę nauczycieli akademickich pracujących we wszystkich wyższych uczelniach publicznych na terenie Łodzi. Takie dane napawają umiarkowanym optymizmem. Jest to bowiem stan obecny, który może się zmieniać pod wpływem kolejnych zmian wymuszanych przez otoczenie. W sytuacji pogłębiania się frustracji nastąpić może opisywana przez P. Sztompkę, „trauma zmiany”, która ma charakter kulturowy, ponieważ dotyczy kulturowej interpretacji potencjalnie traumatycznych sytuacji i zdarzeń ${ }^{34}$. Przed władzami wyższych uczelni publicznych stoją więc wyzwania dotyczące takiego kształtowania kultury organizacyjnej, które pozwoli jeśli nie zwiększyć poziom tych pożądanych społecznie wartości to chociaż utrzymać status quo. Arystoteles twierdził wszak, że

[j]esteśmy bowiem skłonni łatwiej i szybciej wierzyć wszystkim ludziom uczciwym, a zwłaszcza $w$ sprawach niejasnych $i$ spornych. (...). Nieprawda jest (...) że szlachetność mówiącego nie ma żadnego wptywu na siłe przekonywania. Wprost przeciwnie - można powiedzieć - charakter mówcy daje największa wiarygodność (jego argumentom $)^{35}$.

\footnotetext{
${ }^{34}$ P. Sztompka, Trauma wielkiej zmiany. Społeczne koszty transformacji, Instytut Studiów Politycznych Polskiej Akademii Nauk, Warszawa 2000, s. 29.

${ }^{35}$ Arystoteles, op. cit., s. 306.
} 
Tabela 1. Korelacje otwartości/uczciwości z poszczególnymi składowymi tej zmiennej dla grup respondentów wyróżnionych ze względu na typ uczelni oraz pełnienie funkcji kierowniczych.

\begin{tabular}{|c|c|c|c|c|c|c|}
\hline & \multicolumn{5}{|c|}{ Otwartość / Uczciwość } \\
\hline & & 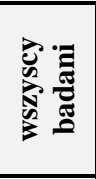 & 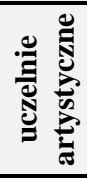 & 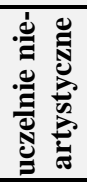 & 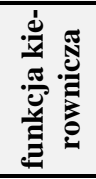 & 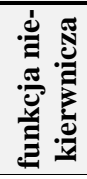 \\
\hline \multirow{3}{*}{$\begin{array}{l}\text { Mogę zwrócić się do mo- } \\
\text { jego bezpośredniego prze- } \\
\text { łożonego, kiedy pojawiają } \\
\text { się problemy w pracy. }\end{array}$} & $\begin{array}{l}\text { Współczynnik } \\
\text { korelacji }\end{array}$ &, $700^{* *}$ &, $707^{* *}$ &, $699^{* *}$ &, $659^{* *}$ &, $709^{* *}$ \\
\hline & Istotność & ,000 &, 000 &, 000 &, 000 &, 000 \\
\hline & $\mathrm{N}$ & 744 & 57 & 687 & 77 & 667 \\
\hline \multirow{3}{*}{$\begin{array}{l}\text { Mogę nie zgadzać się } \\
\text { z moim bezpośrednim } \\
\text { przełożonym. }\end{array}$} & $\begin{array}{r}\text { Wspó } \\
\text { kor }\end{array}$ &, $622^{* *}$ &, $395^{* *}$ &, $642^{* *}$ &, $621^{* *}$ &, $621^{* *}$ \\
\hline & Istotnoś & ,000 & ,002 &, 000 &, 000 &, 000 \\
\hline & 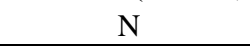 & 744 & 57 & 687 & 77 & 667 \\
\hline \multirow{3}{*}{$\begin{array}{l}\text { Uczestniczę w podejmo- } \\
\text { waniu decyzji dotyczą- } \\
\text { cych mojej pracy. }\end{array}$} & $\begin{array}{r}\text { Wspć } \\
\text { ko }\end{array}$ &, $689^{* *}$ &, $739^{* *}$ &, $684^{* *}$ &, $794^{* *}$ &, $678^{* *}$ \\
\hline & Istotno & ,000 & 000 &, 000 &, 000 &, 000 \\
\hline & 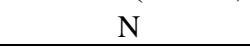 & 744 & 57 & 687 & 77 & 667 \\
\hline \multirow{3}{*}{$\begin{array}{l}\text { Mój bezpośredni przeło- } \\
\text { żony potrafi dochować ta- } \\
\text { jemnicy. }\end{array}$} & $\begin{array}{r}\text { Wspć } \\
\text { ko }\end{array}$ &, $665^{* *}$ &, $809^{* *}$ &, $651^{* *}$ &, $719^{* *}$ &, $661^{* *}$ \\
\hline & Istotno & ,000 & ,000 & ,000 &, 000 &, 000 \\
\hline & & 744 & 57 & 687 & 77 & 667 \\
\hline \multirow{3}{*}{$\begin{array}{l}\text { Otrzymuję rzetelne infor- } \\
\text { macje na temat tego, jak } \\
\text { radzę sobie w pracy. }\end{array}$} & $\begin{array}{r}\text { Wsp } \\
\mathrm{kc}\end{array}$ &, $810^{* *}$ &, $880^{* *}$ &, $802^{* *}$ &, $816^{* *}$ &, $813^{* *}$ \\
\hline & Istotno & ,000 & 000 & ,000 & ,000 & ,000 \\
\hline & & 744 & 57 & 687 & 77 & 667 \\
\hline \multirow{3}{*}{$\begin{array}{l}\text { Otrzymuję rzetelne infor- } \\
\text { macje dotyczące zasad } \\
\text { oceny mojej pracy. }\end{array}$} & $\begin{array}{r}\text { Wspc } \\
\text { ko }\end{array}$ &, $775^{* *}$ &, $858^{* *}$ &, $768^{* *}$ &, $695^{* *}$ &, $782^{* *}$ \\
\hline & Istotność &, 000 &, 000 &, 000 & ,000 &, 000 \\
\hline & $\mathrm{I}$ & 744 & 57 & 687 & 77 & 667 \\
\hline \multirow{3}{*}{$\begin{array}{c}\text { Otrzymuję rzetelne infor- } \\
\text { macje dotyczące sposobu } \\
\text { w jaki rozwiązywane są } \\
\text { moje problemy. }\end{array}$} & $\begin{array}{l}\text { Współczynnik } \\
\text { korelacji }\end{array}$ &, $831^{* *}$ &, $914^{* *}$ &, $824^{* *}$ &, $818^{* *}$ &, $835^{* * *}$ \\
\hline & Istotność (dwustr.) & ,000 & ,000 &, 000 &, 000 &, 000 \\
\hline & $\mathrm{N}$ & 744 & 57 & 687 & 77 & 667 \\
\hline \multirow{3}{*}{$\begin{array}{l}\text { Otrzymuję rzetelne infor- } \\
\text { macje o decyzjach podję- } \\
\text { tych w uczelni, które mają } \\
\text { wpływ na moją pracę. }\end{array}$} & $\begin{array}{c}\text { Współczynnik } \\
\text { korelacji }\end{array}$ &, $700^{* *}$ &, $849^{* *}$ &, $688^{* *}$ & ,699** &, $698^{* * *}$ \\
\hline & Istotność (dwustr.) & 000 & 000 & 000 &, 000 &, 000 \\
\hline & $\mathrm{N}$ & 744 & 57 & 687 & 77 & 667 \\
\hline \multirow{3}{*}{$\begin{array}{l}\text { Otrzymuję rzetelne infor- } \\
\text { macje dotyczące długoter- } \\
\text { minowej strategii mojej } \\
\text { uczelni. }\end{array}$} & $\begin{array}{c}\text { Współczynnik } \\
\text { korelacji }\end{array}$ &, $582^{* *}$ &, $718^{* *}$ &, $569^{* *}$ &, $569^{* *}$ &, $576^{* *}$ \\
\hline & Istotność (dwustr. & , 000 &, 000 &, 000 & ,000 &, 000 \\
\hline & $\mathrm{N}$ & 744 & 57 & 687 & 77 & 667 \\
\hline
\end{tabular}

Źródło: wyniki badań własnych. 
Tabela 2. Korelacje otwartości/uczciwości z poszczególnymi składowymi tej zmiennej dla grup respondentów wyróżnionych ze względu na płeć oraz tytuł/stopień naukowy.

\begin{tabular}{|c|c|c|c|c|c|c|c|}
\hline \multirow{2}{*}{\multicolumn{2}{|c|}{$\begin{array}{l}\text { W jakim stopniu dane stwierdzenie określa } \\
\text { sposoby pelnienia ról w mojej uczelni: }\end{array}$}} & \multicolumn{6}{|c|}{ Otwartość / Uczciwość } \\
\hline & & \multirow{2}{*}{$\frac{\frac{\pi}{0}}{\frac{0}{0}}$} & \multirow{2}{*}{ 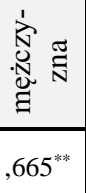 } & \multirow{2}{*}{ 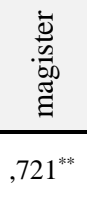 } & \multirow{2}{*}{$\frac{\frac{\bar{t}}{8}}{\frac{\pi}{8}}$} & $\frac{\dot{0}}{\frac{\vec{\theta}}{8}} \dot{0}$ & $\begin{array}{c}\overrightarrow{0} \\
\stackrel{0}{0} \\
\stackrel{0}{0}\end{array}$ \\
\hline \multirow{3}{*}{$\begin{array}{l}\text { Mogę zwrócić się do } \\
\text { mojego bezpośredniego } \\
\text { przełożonego, kiedy po- } \\
\text { jawiają się problemy } \\
\text { w pracy. }\end{array}$} & korelacji & & & & &, $673^{* *}$ &, $598^{* *}$ \\
\hline & Istotność (dwustr.) &, 000 &, 000 & ,000 &, 000 &, 000 & ,000 \\
\hline & $\mathrm{N}$ & 391 & 353 & 170 & 401 & 94 & 79 \\
\hline \multirow{3}{*}{$\begin{array}{l}\text { Mogę nie zgadzać się } \\
\text { z moim bezpośrednim } \\
\text { przełożonym. }\end{array}$} & $\begin{array}{r}\text { Wspó } \\
\text { ko }\end{array}$ &, $652^{* *}$ &, $582^{* *}$ &, $652^{* *}$ &, $609^{* *}$ &, $653^{* *}$ &, $515^{* *}$ \\
\hline & Istotność (d &, 000 & ,000 & 000 &, 000 &, 000 &, 000 \\
\hline & $\mathrm{N}$ & 391 & 353 & 170 & 401 & 94 & 79 \\
\hline \multirow{3}{*}{$\begin{array}{l}\text { Uczestniczę w podejmo- } \\
\text { waniu decyzji dotyczą- } \\
\text { cych mojej pracy. }\end{array}$} & $\begin{array}{r}\text { Wspó } \\
\text { ko }\end{array}$ &, $684^{* *}$ & ,691** & ,696* &, $684^{* *}$ & $664^{* *}$ &, $728^{* *}$ \\
\hline & Istotność (d & ,000 & ,000 & ,000 & 000 &, 000 &, 000 \\
\hline & $\mathrm{N}$ & 391 & 353 & 170 & 401 & 94 & 79 \\
\hline \multirow{3}{*}{$\begin{array}{l}\text { Mój bezpośredni przeło- } \\
\text { żony potrafi dochować } \\
\text { tajemnicy. }\end{array}$} & $\begin{array}{l}\text { Współ } \\
\text { kor }\end{array}$ &, $669^{* * *}$ &, $656^{* *}$ &, $730^{* *}$ &, $644^{* *}$ & ,664 $4^{* *}$ &, $669^{* *}$ \\
\hline & Istotność (d & ,000 & ,000 &, 000 &, 000 &, 000 & ,000 \\
\hline & N & 391 & 353 & 170 & 401 & 94 & 79 \\
\hline \multirow{3}{*}{$\begin{array}{l}\text { Otrzymuję rzetelne in- } \\
\text { formacje na temat tego, } \\
\text { jak radzę sobie w pracy. }\end{array}$} & $\begin{array}{r}\text { Wsp } \\
\text { ko }\end{array}$ &, $823^{* *}$ &, $793^{* *}$ &, $849^{* *}$ &, $794^{* *}$ &, $784^{* *}$ &, $858^{* *}$ \\
\hline & Istotność ( $d$ &, 000 &, 000 &, 000 & ,000 &, 000 &, 000 \\
\hline & $\mathrm{N}$ & 391 & 353 & 170 & 401 & 94 & 79 \\
\hline \multirow{3}{*}{$\begin{array}{l}\text { Otrzymuję rzetelne in- } \\
\text { formacje dotyczące za- } \\
\text { sad oceny mojej pracy. }\end{array}$} & $\begin{array}{r}\text { Wsp } \\
\mathrm{kc}\end{array}$ &, $810^{* *}$ &, $729^{* *}$ &, $853^{* *}$ &, $747^{* *}$ & $668^{* *}$ &, $799^{* *}$ \\
\hline & Istotność (dwustr.) & 000 & 000 &, 000 & 000 &, 000 & 000 \\
\hline & 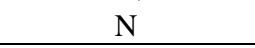 & 39 & 353 & 170 & 401 & 94 & 79 \\
\hline \multirow{3}{*}{$\begin{array}{l}\text { Otrzymuję rzetelne in- } \\
\text { formacje dotyczące spo- } \\
\text { sobu, w jaki rozwiązy- } \\
\text { wane są moje problemy. }\end{array}$} & $\begin{array}{l}\text { Współczynnik } \\
\text { korelacji }\end{array}$ &, $844^{* *}$ &, $814^{* *}$ &, $873^{* *}$ &, $816^{* *}$ &, $809^{* *}$ &, $848^{* *}$ \\
\hline & Istotność (dwustr.) & ,000 &, 000 & ,000 & ,000 &, 000 &, 000 \\
\hline & $\mathrm{N}$ & 391 & 353 & 170 & 401 & 94 & 79 \\
\hline \multirow{3}{*}{$\begin{array}{l}\text { Otrzymuję rzetelne in- } \\
\text { formacje o decyzjach } \\
\text { podjętych w uczelni, } \\
\text { które mają wpływ na } \\
\text { moją pracę. }\end{array}$} & $\begin{array}{c}\text { Współczynnik } \\
\text { korelacji }\end{array}$ &, $713^{* *}$ &, $687^{* *}$ &, $750^{* *}$ &, $677^{* *}$ &, $672^{* *}$ &, $686^{* *}$ \\
\hline & Istotność (dwustr.) & 000 & 000 & 000 & 000 &, 000 &, 000 \\
\hline & iv & 391 & 353 & 170 & 401 & 94 & 79 \\
\hline \multirow{3}{*}{$\begin{array}{l}\text { Otrzymuję rzetelne in- } \\
\text { formacje dotyczące dłu- } \\
\text { goterminowej strategii } \\
\text { mojej uczelni. }\end{array}$} & $\begin{array}{l}\text { Współczynnik } \\
\text { korelacji }\end{array}$ &, $607^{* *}$ &, $560^{* *}$ &, $547^{* *}$ &, $568^{* *}$ &, $554^{* *}$ & ,668 \\
\hline & Istotność (dwustr.) & ,000 &, 000 &, 000 & ,000 &, 000 &, 000 \\
\hline & $\mathrm{N}$ & 391 & 353 & 170 & 401 & 94 & 79 \\
\hline
\end{tabular}

Źródło: wyniki badań własnych. 


\section{Bibliografia}

Arystoteles, Dzieła Wszystkie, Etyka Eudemejska, Księga VII, Wydawnictwo Naukowe PWN, Warszawa 1996, tom 6.

Giddens A., Socjologia, Wydawnictwo Naukowe PWN, Warszawa 2004.

Gitomer J., Turkusowa książeczka zaufania. Jakje zdobyć, wzmacniać i utrzymać, by stać się zaufanym doradca $w$ biznesie $i$ w życiu, Wydawnictwo Studio EMKA, Warszawa 2011.

Hofstede G., Kultury i organizacje, Polskie Wydawnictwo Ekonomiczne, Warszawa 2000.

Ilustrowany Słownik Języka Polskiego, red. E. Sobol, Wydawnictwo Naukowe PWN, Warszawa 1999.

Jeremus A., Nowoczesny wizerunek nauczyciela akademickiego [w:] Nauczyciel akademicki jako ogniwo jakości ksztatcenia, red. K. Jankowski, B. Sitarska, C. Tkaczuk, Akademia Podlaska, Siedlce 2003.

Kodeks Etyki Nauczyciela Akademickiego Uniwersytetu Gdańskiego, http://arch.ug.edu.pl/ $\mathrm{pl} / \mathrm{dz} \_$org/prawo/us/2007/zal40u07a.htm.

Kozak A., Zatrzymać pracownika poprzez kształtowanie kultury organizacyjnej, www.irb.pl/ wiedza-dla-biznesu/zatrzymac-pracownika-poprzez-ksztaltowanie-kultury-organizacyjnej/.

Koźmiński A.K., D. Jemielniak, Zarządzanie od podstaw, Wydawnictwa Akademickie i Profesjonalne, Warszawa 2008.

Lachowski S., Droga ważniejsza niż cel, Wydawnictwo Studio EMKA, Warszawa 2012.

Malorny I., Wizerunek wspótczesnego nauczyciela - implikacje praktyczne jakości ksztatcenia w zawodzie [w:] W obliczu nowych wyzwań. Dylematy młodej kadry akademickiej, red. M. Kulesza, M. Kafar, Wydawnictwo Uniwersytetu Łódzkiego, Łódź 2010.

Palmer R.E., Przywództwo doskonate, Wolters Kluwer business, Warszawa 2010.

Putnam R.D., Samotna gra w kręgle. Upadek i odrodzenie wspólnot lokalnych w Stanach Zjednoczonych, Wydawnictwa Akademickie i Profesjonalne, Warszawa 2008.

Ryan L.V., Wyzwania moralne w czasach transformacji gospodarczej, „Ruch Prawniczy, Ekonomiczny i Socjologiczny" 1996, vol. 58, nr 1.

Rybak M., Etyka menedżera - społeczna odpowiedzialność przedsiębiorstwa, Wydawnictwo Naukowe PWN, Warszawa 2004.

Shockley-Zalabak P., K. Ellis, R. Cesaria, Building the High-Trust Organization, John Wiley \& Sons, IABC Research Foundation, 2010.

Stownik 100 tysięcy potrzebnych słów, red. J. Bralczyk, Wydawnictwo Naukowe PWN, Warszawa 2005.

Stownik Języka Polskiego, PWN, http://sjp.pwn.pl.

Stachewicz K., Aksjologia prawdy i uczciwości. Krótkie wprowadzenie w problematykę [w:] Prawda i uczciwość w życiu publicznym, red. R. Wiśniewski, Towarzystwo Naukowe w Toruniu, Torun 2014.

Stachowicz-Stanusch A., Potęa wartości. Jak zbudować nieśmiertelna firmę, Helion Gliwice 2007. 
Sztompka P., Trauma wielkiej zmiany. Spoleczne koszty transformacji, Instytut Studiów Politycznych Polskiej Akademii Nauk, Warszawa 2000.

Śnieżyński M., O autorytecie nauczyciela akademickiego, www.wsp.krakow.pl/konspekt /konspekt3/sniezynski.html.

Świątek-Barylska I., Lojalność pracowników współczesnych organizacji. Istota i elementy składowe, Wydawnictwo Uniwersytetu Łódzkiego, Łódź 2013.

Ustawa z dnia 27 lipca 2005 r. Prawo o szkolnictwie wyższym (Dz. U. z 2012 r., poz. 572 z późn. zm.).

von Weltzien Hoivik H., Accessing, Managing and Sustaining Moral Values in Organizations: A Case Study [w:] Moral Leadership in Action. Building and Sustaining Moral Competence in European Organizations, red. H. von Weltzien Hoivik, Edward Elgar Publishing, Cheltenham 2003. 